\title{
PLANT BIOLOGY A RESOURCE FOR PROSPERITY
}

\author{
MARTIN M. KATER (*) \\ Nota presentata dal s.c. Martino Bolognesi \\ (Adunanza del 20 dicembre 2012)
}

SunTO. - L'agricoltura in tutto il mondo si trova ad affrontare molte sfide. La popolazione mondiale in rapida crescita, i cambiamenti climatici, il bisogno crescente di un'agricoltura sostenibile richiedono soluzioni immediate per garantire una migliore stabilità economica, sociale ed ambientale. Un contributo importante è richiesto alla ricerca sulle piante attraverso lo sviluppo di tecniche sempre più innovative. Tuttavia c'è ancora poco investimento in questo campo di ricerca nonostante la crescente attenzione sia scientifica che politica verso i problemi legati alla agricoltura. E' quindi importante che questo cambi e che si comprenda come investire nella ricerca sulle piante sia un investimento per il futuro della nostra società.

$* * *$

ABSTRACT. - Worldwide agriculture is facing many challenges. A fast growing world population, a changing climate and an increasing need for sustainability call for immediate solutions to guarantee environmental, social and economic stability. An important contribution will have to come from innovative plant research. However, despite that there is more and more scientific and political attention for problems related to agriculture, there is still little investment in this field of research. It will be important that this will change and that we start to realize that investing in plant research is an investment in the future of our society.

(*) Department of Biosciences, Università degli Studi di Milano, Milan, Italy.

E-mail: martin.kater@unimi.it 
Plants are essential for our existence and form the fundaments for our modern society. Apart from oxygen many products come from plants and our daily life without them will be absolutely impossible. For instance they are the main source of food (cereals, fruits, beans etc.), medicines, clothes, paper, wood, etc. They are also becoming an important resource for bioenergy. It is clear that plants are important for our society but also provide many opportunities for the future.

Unfortunately, the importance of plant research is often not enough recognized, despite the fact that difficulties related to agriculture are more and more becoming evident. Therefore, plant scientists are asking for special attention for these problems since many difficulties are foreseen within the next 50 years. Examples are, the rapid increase of the world population, water shortage, climate change, limitations in natural resources, costs of energy and this all goes together with a deep global economical crisis.

For many years in Europe it was politically wrong to discuss about yield improvement in agriculture, since we throw in our rich Western society something like $30 \%$ of our food in the garbage bin. However, in the mean time the world population has grown with unprecedented speed resulting today in almost 1 billion people on Earth that have not enough calorie intake. Remain the contrasting data that show that in our Western society more than one billion people are obese! Nonetheless, the prognoses for the growth of the world population are showing a further rapid increase towards 9 billion people that will be reached between 2040 and 2050, which means feeding about 2 times the population of China extra within in the next 40 years. In principle, based on the agricultural practice that we apply to day, this will be feasible. We only have to use more land, more water, more fertilizers, more pesticides etc. It is clear that this is not a sustainable option and will not bring solutions for the very poor people. Furthermore, not solving this problem is rather risky since history has learnt that hunger has always resulted in social instability.

What is needed is a second green revolution but this time it should be a sustainable agricultural revolution. Is this possible? Plant scientists think it is. Many examples from basic and applied research show that in nature characters can be identified that would be very helpful for agriculture, for example, drought tolerance of plant species that grow in the desert, disease resistance available in often untapped wild varieties. (Molecular) Geneticists and plant breeders are nowadays closely collaborating and using the available biodiversity for introgres- 
sion of important characters into local crops for yield improvement and to grow them cheaper and more environmentally sustainable. Examples are the identification of the SUB1A [1] and PSTOL1 [2] genes. Both genes have been lost during the domestication of rice and are only found in wild varieties. SUB1A provides resistance to flooding of rice paddy fields, which often occurs in countries like Bangladesh and which leads to important harvest losses. The SUB1A gene prevents that rice plants start to elongate when they are under water and secures that when water levels return to normality the plants produce an almost normal amount of seeds. The PSTOL1 gene is important for root development and increases drastically the number of roots. Plant breeders for a long time neglected looking at roots and they focused mainly on the areal parts of the plant. The presence of the PSTOL1 gene, again identified in a non-commercial rice variety, increases the uptake of nutrients such as phosphor, which makes these varieties able to grow on soil that is low in phosphor and no fertilizers are needed. This saves money and makes it possible to obtain improved harvest yields also in countries with poor soil conditions. It is also important to notice that natural resources for phosphor are extremely limited on Earth.

These and many other examples make clear that plant science can provide important solutions for agriculture. Worldwide scientists are doing basic and applied research using model plants like Arabidopsis thaliana and high-technology approaches. Over the last 30 years this has led to an enormous amount of information and deep knowledge about plant processes. Although we are at the tip of the iceberg concerning our knowledge of how plant function, still it is possible to use this knowledge for important agricultural innovations. Therefore it is important to realize that basic research lays the fundaments for more applied research and it is worrying that globally funding goes mainly into applied plant research. However, even more worrying is that the total amount of money invested in plant research is dramatically low, which is only about $5 \%$ of the total global R\&D budget [3]. Bill Gates in his Annual Letter of the Bill \& Melinda Gates Foundation in 2012 commented on this as follows: "Given the central role that food plays in human welfare and national stability, it is shocking - not to mention short-sighted and potentially dangerous - how little money is spent on agricultural research" [4].

It is clear that if we want to provide timely solutions for the increasing world population and to make our agriculture globally more 
environmentally and economically sustainable we will have to invest in basic and applied plant research and to invest into a young generation of well trained plant researchers. Let's hope that policy makers get this more long-term vision!

Martin Kater is Professor of Genetics. His research group is focusing on the molecular genetic control of flower and seed development.

\section{REFERENCES}

[1] Xu et al., Nature 442, 705-708 (2006).

[2] Gamuyao et al. Nature 488, 535-539 (2012).

[3] Food: The growing problem, Nature 466, 546-547 (2010).

[4] http://www.gatesfoundation.org/who-we-are/resources-and-media/annual-letters-list/annual-letter-2012. 